\title{
Kussmaul's sign due to right ventricular pacing completely disappeared after atrial pacing
}

\author{
Takeshi Arita, ${ }^{1}$ Akihiro Hayashida ${ }^{2}$
}

${ }^{1}$ Medicine and Biosystematic Science, Kyushu University Graduate School of Medicine, Fukuoka, Japan

${ }^{2}$ The Sakakibara Heart Institute of Okayama, Okayama, Japan

\section{Correspondence to}

Dr Akihiro Hayashida,

h-aki@msc.biglobe.ne.jp

Accepted 30 November 2018

\section{DESCRIPTION}

A 72-year-old woman was hospitalised with a history of dyspnoea with mild exertion over the course of 2 months. Three years previously, she had undergone surgery for atrial septal defect repair, and a VVI pacemaker was implanted for symptomatic sinus bradycardia. Her blood pressure at admission was $102 / 70 \mathrm{~mm} \mathrm{Hg}$, and a heaving internal jugular vein was observed during systole, which was reflected by the V-wave. Kussmaul's sign, ${ }^{1}$ which involves increased central venous pressure on inspiration, was observed (video 1). Echocardiography revealed a preserved left ventricular ejection fraction with moderate tricuspid regurgitation. Electrocardiography revealed no apparent P-wave with regular ventricular pacing of $80 \mathrm{bpm}$. An electrophysiological study was performed, showing sinus bradycardia at baseline with ventriculoatrial (VA) conduction during right ventricular pacing (figure 1). An additional atrial lead was inserted, leading to AAI pacing to improve haemodynamics. The prominent systolic jugular wave and Kussmaul's sign completely disappeared immediately after the procedure (Video 2). At the 1-year follow-up, the

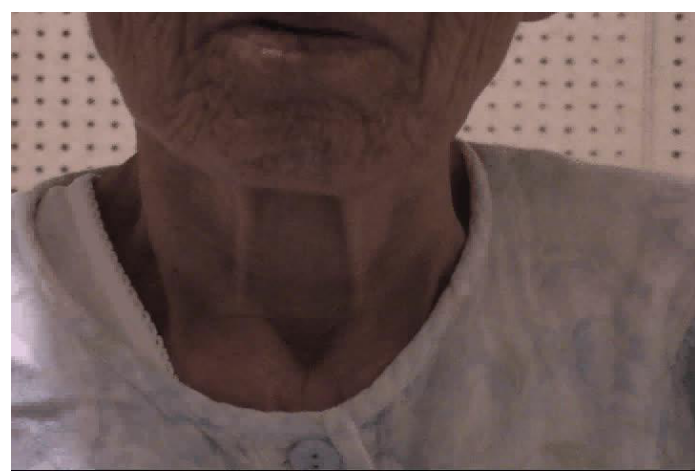

Video 1 Heaving internal jugular vein with Kussmaul's sign.

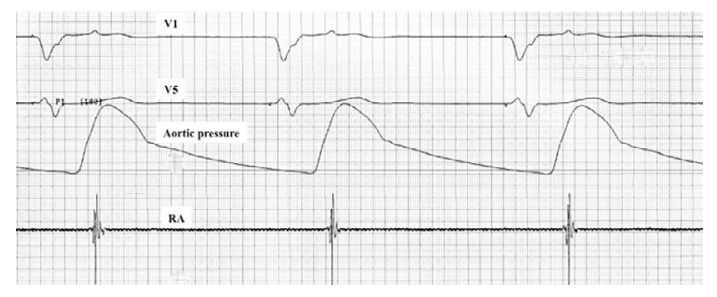

Figure 1 Electrophysiological study during ventricular pacing of $60 \mathrm{bpm}$. Ventriculoatrial conduction is clearly shown. The paper speed was $100 \mathrm{~mm} / \mathrm{s}$. V1 and V5 represent electrocardiograms. $\mathrm{RA}$, right atrium.

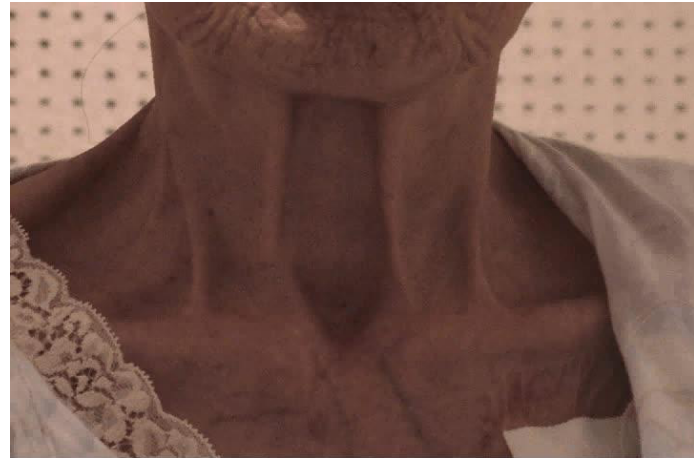

Video 2 Complete disappearance of symptoms, such as the heaving internal jugular vein and Kussmaul's sign.

patient was free from dyspnoea even on moderate exertion.

Atrioventricular (AV) asynchrony is a major limitation of VVI pacing. For patients who have constant VA conduction, such as this patient, haemodynamic parameters may deteriorate because of simultaneous electrical and mechanical activation of the atria and ventricles against closed AV valves. This can result in reflux of blood into the neck veins. Similar to the pathomechanism during atrioventricular nodal reentrant tachycardia which manifests as the frog sign, ${ }^{2}$ VVI pacing in the present case resulted in Kussmaul's sign. Kussmaul's sign is a known manifestation of heart failure.

VVI (leadless) pacemaker implantation offers a less invasive antibradycardic treatment option in the elderly and is increasingly being performed. Kussmaul's sign in VVI pacemaker recipients may indicate the presence of VA conduction

\section{Patient's perspective}

It was a fantastic experience. After an additional lead was inserted, my physical examination indicated that my symptoms had improved.

\section{Learning points}

Right ventricular pacing with ventriculoatrial (VA) conduction may cause heart failure.

- Kussmaul's sign disappears soon after improvement of symptoms associated with heart failure.

- Kussmaul's sign in VVI pacemaker recipients may indicate the presence of VA conduction and haemodynamic compromise. 


\section{Images in...}

and haemodynamic compromise. Therefore, these patients should be considered for dual chamber pacing, enabling AV synchrony.

Contributors TA, MD: drafting of the manuscript. $A H, M D$ : revising the manuscript.

Funding The authors have not declared a specific grant for this research from any funding agency in the public, commercial or not-for-profit sectors.

Competing interests None declared.
Patient consent for publication Obtained.

Provenance and peer review Not commissioned; externally peer reviewed.

\section{REFERENCES}

1 Rosenberg AJ, Satchithananda DK. Images in cardiovascular medicine. Kussmaul's sign in right ventricular dysfunction. Circulation 2007;115:e49-50.

2 Contreras-Valdes FM, Josephson ME. "Frog Sign" in Atrioventricular Nodal Reentrant Tachycardia. N Engl J Med Overseas Ed 2016;374:e17.

Copyright 2018 BMJ Publishing Group. All rights reserved. For permission to reuse any of this content visit

https://www.bmj.com/company/products-services/rights-and-licensing/permissions/

BMJ Case Report Fellows may re-use this article for personal use and teaching without any further permission.

Become a Fellow of BMJ Case Reports today and you can:

- Submit as many cases as you like

Enjoy fast sympathetic peer review and rapid publication of accepted articles

- Access all the published articles

Re-use any of the published material for personal use and teaching without further permission

For information on Institutional Fellowships contact consortiasales@bmjgroup.com

Visit casereports.bmj.com for more articles like this and to become a Fellow 